\title{
Isolation and Identification of Methicillin Resistance Staphylococcus aureus and Detection their Ability to the Production of Virulence Factors
}

\author{
Angham Najah Al-Khafaji \\ Pharmacy Department, Kufa Technical Institute, Al-Furat Al-Awsat Technical University, 31001 Al- \\ Kufa, Al-Najaf, Iraq. \\ anghamnajah@gmail.com
}

Submission date:- 15/3/2018 Acceptance date:- 8/5/2018 Publication date:- 4/9/2018

Keywords: Staphylococcus aureus, Antibiotics, Methicillin, Virulence factors.

\begin{abstract}
* Objectives: Isolation and Identification of S.aureus and study their susceptibility to the production of virulence factors.

* Methods: A total 50 clinical specimens of Staphylococcus aureus isolates were collected in AL- Najaf ALAsharaf governorate during the period of (10/10/2013-20/1/2014) by the cultural characteristic colonies, microscopic for cells, biochemical tests, antibiotics susceptibility test to Staphylococcus aureus using an antibiotic diffusion disc assay, in addition to studying the virulence factors produced from S.aureus .

* Results: The results show that the Staphylococcus aureus resistant to methicillin formed $70 \%$ and $30 \%$ of isolates were sensitive to the same antibiotics. Tested 10 isolates to methicillin resistant for their efficiency in forming the highest inhibitory areas for testing their sensitivity to other antibiotics used, the results show S.aureus resistant to penicillin about $100 \%$, while there is no resistance to CO-Trimethoprim because it was sensitive completly $100 \%$.

The susceptibility investigated of Staphylococcus aureus resistance methicillin isolates to the production of biofilm and slime layer with using both tube method and growth on Congo red agar respectively. Ten isolates of S.aureus were tested based on resistance to methicillin and their high susceptibility to the production of the biofilm and the slime layer.

* Conclusion: So we conclusion, they have Staphylococcus aureus is highly resistant to $\beta$ - Lactam antibiotics and the CO-trimethoprim is the most effective in the inhibiting growth of this bacteria. In addition to its ability to produce virulence factors. The increase cause bacterial resistance to our local isolates may be due to the frequent use of antibiotics, which allowed for increased bacterial resistance to various antibiotics.
\end{abstract}

\section{1-Introduction:-}

In recent years, there has been an alarming increase in hospital-related infections caused by multidrugresistant Staphylococcus strains, Shown some strains have no resistance to more than 20 antibacterial compounds, including antiseptics[1]. Staphylococcus aureus is one of the most important pathogens that is capable of causing various types of infections at multisite in human body, The pathogenesis is linked to its ability to produce many virulence factors, which include the production of toxins, extracellular enzymes and other factors, which gives bacteria the ability to multiply and spread within host tissues as well as the high resistance and multiple antibiotics, especially belonging to the group $\beta$ - Lactam and aminoglycoside, making it a major pathogen causing hospitalnosocomial infection [2]. And that the transmittability of antimicrobial resistance between bacterial strains is a health problem, including resistance to vancomycin, which is used as an alternative to beta-lactam antibodies to gram-positive bacteria treated, particularly S.aureus [3]. Methicillin Resistance Staphylococcus aureus (MRSA) has also caused many diseases, including endocarditis and chronic osteoarthritis [4]. Although, MRSA has many mechanisms to increase pathogenicity and virulence, including biofilm production and host cell adhesion [5]. 
Given for demonstrating bacteria $S$. aureus from resistance to many antibiotics, especially those resistant to methicillin, so the study aimed to isolate and identification of S.aureus and study their susceptibility to the production of virulence factors.

\section{2-Materials and Methods}

Specimen collection and culture:-

A total of 50 clinical isolates of Staphylococcus aureus were collected from different sources in Najaf Governorate for the period from (10/10/2013-1/20/2014).

S. aureus were cultured on the Mannitol salt agar and incubated at $37{ }^{\circ} \mathrm{C}$ for $24 \mathrm{~h}$ to obtain the colonies, then transferred and purified into individual colonies.

\section{3-Studying the virulence factors produced from Staphylococcus aureus:-}

\subsection{Antibiotics sensitivity test :-}

The antibiotic sensitivity test of S.aureus including (Ampicilin, Amoxicillin / Clavulanic Acid, Pencillin, CO-Trimethoprim, Ticarcillin / Clavulanic Acid, Gentamicin, Ciprofloxacin, Ceftriaxone, Cefixime, Vancomycin, Kanamycin Chloramphenicol and Methicillin) was used. The Muller Hinton agar is used by adding $0.3 \mathrm{ml}$ of bacterial implant and spread in the middle of the surface media by the spreader diffuser and stayed the dishes for 10-20 minutes to complete the implant absorption. The disc containing antibiotics were placed on the center surface of the implant with sterile forceps with light pressure on the surface of the disc to fix it on the center surface of the pelvis. The dishes were incubated with a temperature of $37{ }^{\circ} \mathrm{C}$ for $24 \mathrm{~h}$ after reading the results is determined by an enclosed ruler. The bacteria are sensitive and resistant, depending on the specifications in [6].

\subsection{Slime layer production:-}

Congo-red agar was used to investigate the ability of bacteria to the production of slime layer, culture S.aureus on Congo-red agar and incubated for $24 \mathrm{~h}$ at $37{ }^{\circ} \mathrm{C}$. Growth was observed by observing microbial colonies and changing their color to black to indicate slime layer production while colonies appear in the same color media indicates that the inability of the bacteria to produce Slime layer [7].

\subsection{Boifilm production:-}

Brain heart infusion sucrose broth (BHI suc) was used to investigate the ability of bacteria to biofilm production, this method was described by (8) and includes:

* Intake $10 \mathrm{ml}$ of brain heart infusion broth with $2 \%$ sucrose, culture S.aureus and incubate at $37{ }^{\circ} \mathrm{C}$ for 24 hours.

* Dissolve the contents of the medium and wash using PBS with pH7.2.

* Dry the tube and dye a with crystal violet at concentration $0.1 \%$ for 10 minutes. The dye is then removed from the tube and washed with deionized water.

* Dry the tube and turn it to watch the biofilm composition at the bottom.

* Biofilm formation is a positive result when the formation of a film layer is observed around the bottom wall of the tube.

\subsection{Capsule production detection:-}

This test was performed using the Indian ink stain to detect the ability of the S.aureus to production of capsule. By taking single colonies of bacterial implants and placing a drop of stain that mixed the colony with stain a wellmixed and then covering the sample with the cover slide. It was then dried by air (at room temperature) and then examined under the oil lens of the microscope to observe the capsule [9]

\subsection{Gelatin hydrolysis test:-}

This test was used to investigate the ability of the bacteria to the production of gelatinase enzyme, which works to dissolve the gelatin. The bacteria were cultured in the Gelatin liquefaction medium and incubated $37{ }^{\circ} \mathrm{C}$ for $24 \mathrm{~h}$. The positive result was observed by the gelatin dissolve after being placed in a snow bath (ice) for $2 \mathrm{~h}$. The negative result was that the gelatin was not dissolved [10]. 


\subsection{Detection of the $\beta$-hemolysin production:}

This test was conducted to investigate the ability of the bacteria to the production of beta toxin, which completely dissolves the blood. Culture bacteria on blood agar incubated $37^{\circ} \mathrm{C}$ for $24 \mathrm{~h}$, and the positive result was observed when blood was analyzed [11].

\section{3- Results and Discussion:-}

Collect 50 samples of Staphylococcus aureus were isolated and diagnosed from different sources as shown in Table (1) as follows:-

Table (1): distributed of $S$. aureus according to their sources of isolation

\begin{tabular}{|c|c|c|c|}
\hline $\begin{array}{c}\text { Total } \\
\text { sample }\end{array}$ & Source & $\begin{array}{c}\text { Number S.aureus } \\
\text { isolate }\end{array}$ & $\begin{array}{c}\text { Total } \\
\text { Number }\end{array}$ \\
\hline \multirow{6}{*}{50} & Urine & 2 & 15 \\
\hline & Ear swab & 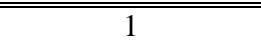 & 2 \\
\hline & Seminal fluid & 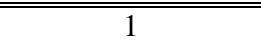 & 2 \\
\hline & Vaginal swab & $\overline{c 1}$ & 2 \\
\hline & "Wound \& Burn & $\begin{array}{ll}1 \\
\end{array}$ & 10 \\
\hline & Nose swab & 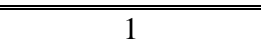 & 19 \\
\hline
\end{tabular}

Growth S.aureus isolates on Mannitol salt agar aerobically by changing the color of the medium from pink to yellow due to their ability to ferment mannitol sugar and some isolates did not change The color of the medium due to inability to ferment mannitol sugar, which is consistent with [12] .

While showing the microscopic examination of S.aureus that its positive globular cells, gram positive and agriculture with pairs or quadric or in the form bunches of grapes, which is consistent with the phenotypic characteristics of [13]. As shown in Figure (1).

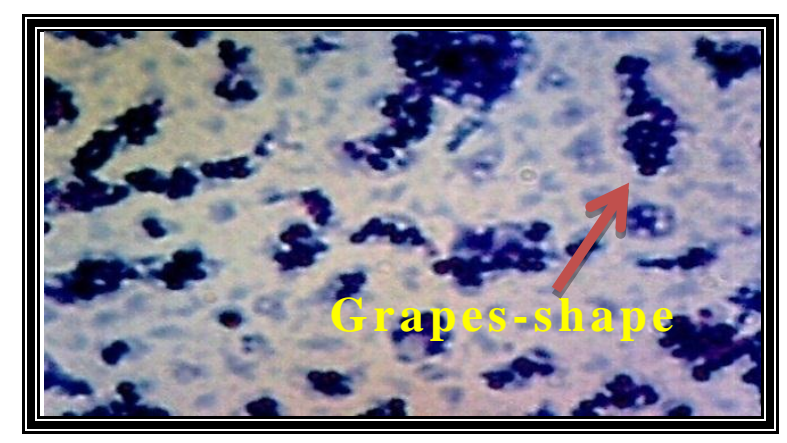

Figure (1):Cells bacteria S.aureus stained with Gram stain magnification (1000X) 


\section{4- Biochemical Examination:-}

Our study the results of the biochemical tests of Staphylococcus aureus obtained from different sources. The results showed that all S.aureus isolates were positive for the catalase test because they are aerobic or facultative anaerobic bacteria, which in this capacity can produce the catalase enzyme, which protects it from the toxic effect of hydrogen peroxide produced during metabolic processes and its inability to produce oxidase. This result agreed with [14],[15]. It also showed a positive result of coagulase enzyme.

\section{5- Antibiotic sensitivity test:-}

The susceptibility of all S.aureus isolates was investigated using the antibiotic sensitivity test for methicillin and based on the methods given in [6]. The main objective of this test is to study the relationship between resistance and sensitivity of antibiotic and the pathogenicity extent of the S.aureus to multiply resistant to antibiotic by examining the similarities and differences in the resistance pattern between bacteria isolates of the Isolated from different sources. That high levels of resistance to methicillin to ratio [35]70\% and [15] 30\% were sensitive to methicillin as shown in Figure (2).

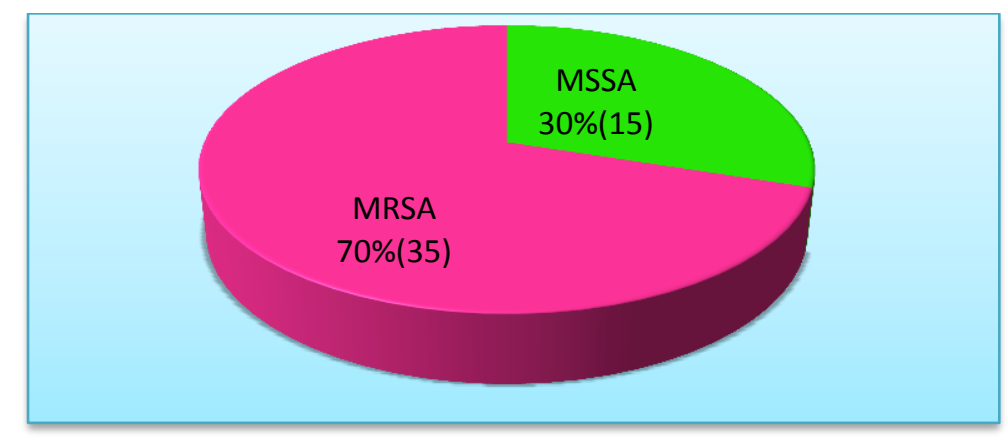

Figure (2): Percentage of Staphylococcus aureus isolates resistance and sensitive to the methicillin

These results agree with the study of [16] which recorded a resistance rate of about $80.3 \%$, while $16.4 \%$ of isolates were moderately resistant, while $3.3 \%$ were sensitive. [17] showed that the resistance ratio to about $90.90 \%$.[18] showed that the resistance ratio was about $94.3 \%$. These results not agreed with [19] found that about $51.4 \%$ of isolates were resistant to methicillin, while $48.6 \%$ were sensitive to figure (3).

In the present study and other studies the variation in resistance ratios may be due to the diversity of isolated sources, including Staphylococcus aureus, and to the change in methicillin resistance genes of the same bacteria.

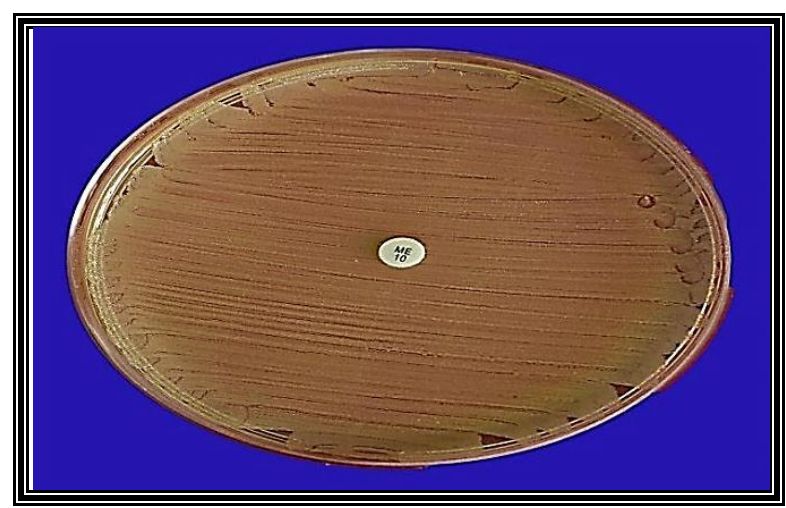

Figure (3): Resistance S.aureus to methicillin

Tested 10 isolates to methicillin resistant for their efficiency in forming the highest inhibitory areas for testing their sensitivity to other antibiotics used in the study.

The results show the $\beta$ - Lactam antibiotic, represented by Methicillin, Amoxicillin and Ampicillin high resistance representatives $(100 \%)$.

As for the antibiotic Penicillin (G) its resistance was 90 (9)\%, while all isolates were resistant to Ticarcillin100\%.

The Cephalosporin group includes Cefixime, Ceftriaxone, was resistant to $100 \%$ as shown in Figure (4). 
Act $\beta$ - Lactam antibiotics to inhibit the manufacturing of process the bacterial cell wall by interfering with the manufacturing of process the peptidoglycan layer, the causes of this resistance may be due to the secretion of $\beta$ Lactam enzymes, which may be plasmid or chromosome, or resistance may be due to the secretion of bacteriostatic enzymes, which may be plasmid or chromosome, it is also used to neutralize the effectiveness of beta lactam antibiotic by breaking beta lactam ring it into the group of penicillins and cephalosporins [20]. Antibiotics binding to proteins responsible for the cellular wall durability called Penicillin Binding Proteins, the cause of the resistance may also be due to the presence of the mecA gene, which reduces the relevance of binding antibiotic to the proteins responsible for the cell wall strength called Penicillin Binding Proteins [21]. The Vancomycin was resistant to $100 \%$, The vancomycin is considered Glycopeptides antibiotic decreased susceptibility of $S$. aureus strains to vancomycin may be related to a change in the bacterial target. Studies have documented thickening of the bacterial cell wall that traps the vancomycin molecules However, a decrease in peptidoglycan cross-linkage and a high content of free D-alanine-D-alanine residues in the cell wall may increase the resistance of the strain, a resistance resulting from the transmission of coded genes to the resistance characteristic of this antibiotic and portable to conjugated plasmids or transposon genes from other strains and species of bacteria S.aureus, giving it a resistance within a short period [22]. Although it is effective against Staphylococcus aureus, it has been reported to be resistant to it, which may be due to increased cell wall thickness and decrease cell wall sensitivity to the analyze enzymes [23]. This result is not agreed with [17] which found that the resistance was $2.27 \%$.

As for its resistance to Chloromphenicol antibiotic was [1]10\%, and the resistance could be due to the breakage of the drug by Chloramphenicol acetyl transferase [24].This bacteria not resistance to the COtrimethoprim because they were sensitive to it $100 \%$. While antibiotics aminoglycoside group include Gentamycin and Kanamycin have a resistance rate of 10 [1] and [4] 40\%, respectively. The resistance of the bacteria may be attributed to aminoglycoside antibiotics into three mechanisms: Modification of the antibiotic molecule by adenylating, Phosphorylating, Acetylating or a chromosomal mutation such as a mutation in the encoded gene of the target protein under the 30S ribosome causing the loss of the antibiotic to bind to the target protein and reduce the cell's permeability to the antibiotic [25]. The resistance to Quinolones include Ciprofloxacin was 20\% and that the causes resistance of the isolates under study for the Quinolones was due to a change in the target site of the binding antibiotic to the enzyme [26]. The change in GyrA, which is one of the building blocks of the DNA gyrase [17].

Several studies have confirmed the resistance of Staphylococcus aureus to penicillin [16] which found that the bacteria strain of penicillin resistant with ratio (100\%), as well as the study by [27] Show result not found of efficiency to the penicillin against $S$. aureus. [28] noted that the cause resistance of $S$. aureus to penicillin is due to its production of penicillinase enzymes as shown in Figure (4).

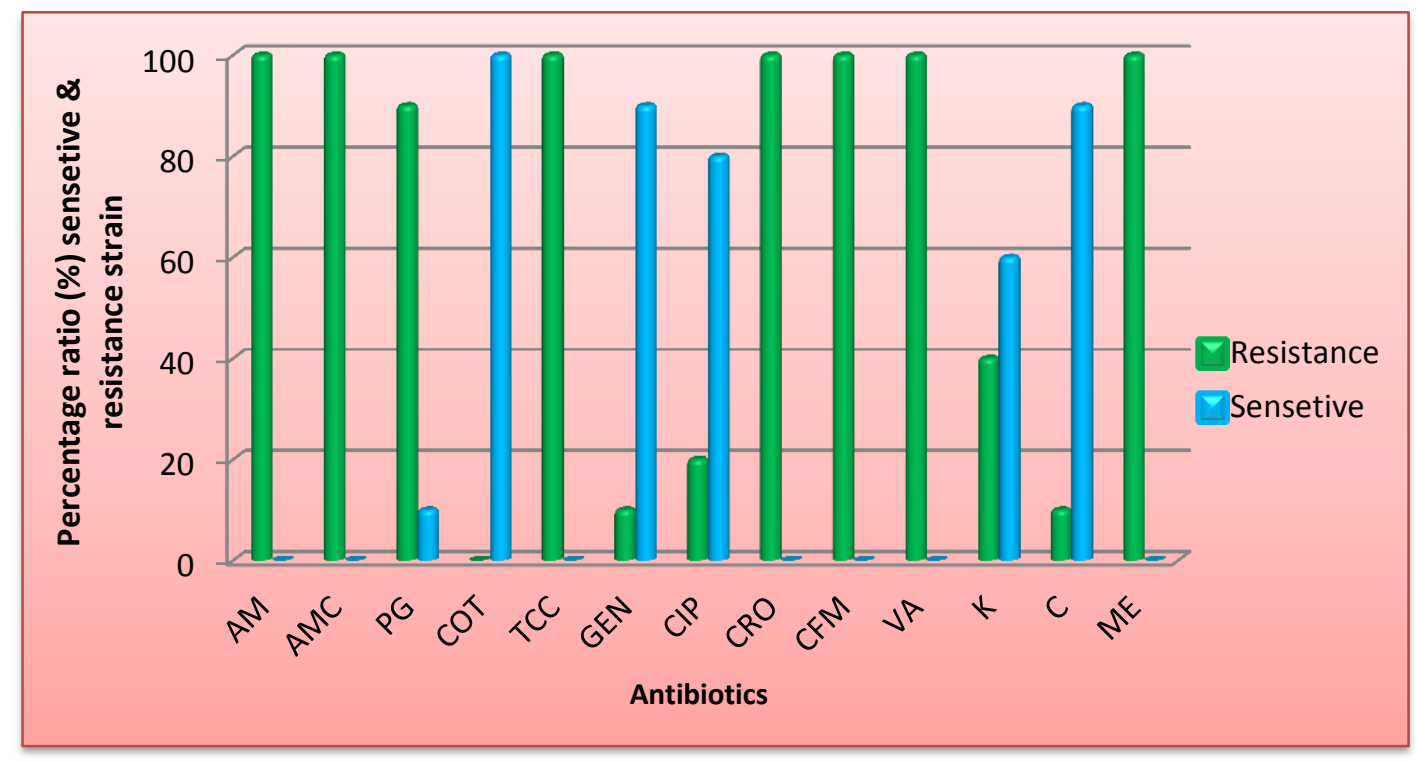

Figure (4): Antibiotic susceptibility test MRSA by disc diffusion method $(n=10)$

CRO: Ceftriaxone

CFM: Cefixim

VA: Vancomycin

COT: CO-Trimethoprim

TCC: Ticarcillin /Clavulanic acid

GEN: Gentamicin
AM: Ampicilin

AMC: Amoxicillin /Clavulanic acid PG: PencillinG

\section{K: Kanamycin}

C:Chloramphenicol

ME:Methicillin 


\section{6- CIP : Ciprofloxacin}

The production of $S$. aureus for $\beta$-lactamase inhibitors of penicillin is highly resistant to this antibiotic. In general, S.aureus isolated from society are more sensitive to antibiotics that do not belong to the non- $\beta$-lactam antibiotisc group than those isolated from the hospital environment [29]. It is difficult to determine the relationship between antibiotic use and resistance, the use of antibiotics for clinical purposes alone does not explain the high dominance of resistant organisms in many developed countries [30], [31]. Therefore, the widespread clinical use of antibiotics leads to a high increase in resistance, especially among people are in hospital [32].Other studies have also shown that Community Acquired Methicillin Resistance Staphylococcus aureus (CA-MRSA) have the ability to spread their colonies more than the Healthy Acquired Methicillin Resistance Staphylococcus aureus (HAMRSA), and this variability is due to the CA-MRSA contain psm-mec gene responsible for the spread of colonies and then causing damage [27].

The reason for the variation in bacterial resistance to various antibiotics is due to its ability to prevent the bactericidal effect of the antibiotic by different methods, including inhibiting the antibiotic by producing inhibitory substances such as beta lactamase or the tolerance of the bactericidal effect of the antibiotic, or cellular pathway alteration or by altering membrane permeability [33]. The cell wall play important role in increasing the resistance of the bacteria to these antibiotics. Several studies have shown that processing the medium with the amino acids needed to build the cell wall, such as alaninoalcottamate and sugars such as glucose and $\mathrm{N}$-acetyl glucosamine helps the cell to build a thick cell wall to help show a high level of resistance [34],[7].

\section{7- Capability Methicillin Resistance Staphylococcus aureus to the Production Slime Layer:-}

MRSA was detected the ability in the production of the slime layer using Congo-red agar described by the scientist [35]. 10 isolates were detected from MRSA, The results showed that 8 isolates of MRSA to change in developing colony color on the Congo- red agar from red to black or gray while the remaining two isolates did not show any change in the color of the medium, This indicates that these isolates were not production of the slime layer, as shown in Figure (5).

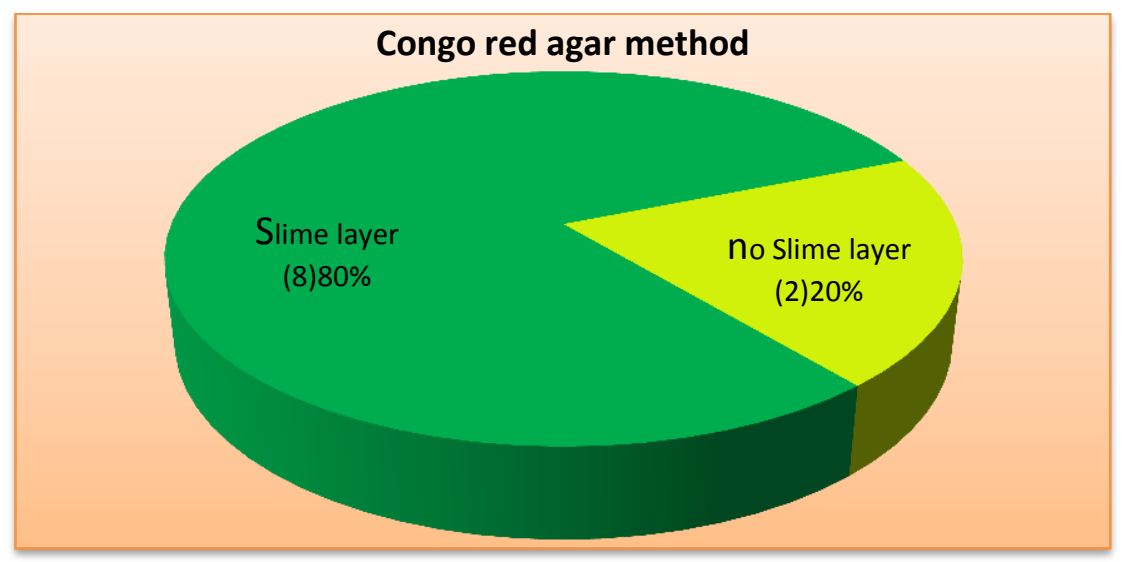

Figure (5): Production and not production isolates of the slime layer

The results of the investigation of slime layer production in MRSA isolates were consistent with several studies that confirmed the MRSA susceptibility to production of slime layer. The slime layer formed from the ability of bacteria to produce Glycocalyx which surrounds the bacterial cell, Glycocalyx is an extracellular substance made up of polysaccharide or polypeptide or both. This layer works to protect the bacterial cell from dehydration and its loss of nutrients, Casing the Glycocalyx is irregular when it is linked to the cell wall in a fragile way known as the slime layer. While Glycocalyx is made up of the basic material that is closely related to the cell wall and is then known as Capsule [36],[37]. The slime layer works on the bacterial cell packaging, forming thin, living membranes known as biofilm its act as a buffer that inhibits the antibiotic influence within the bacteria cell and thus confers resistance [38].

This result agreed with the study of [39] which showed about $77.8 \%$ of S.aureus isolates were slime layerproducing. While agreeing with the study [40] which showed about $60 \%$ of the isolates he studied were produced of this layer. It was observed that the results obtained did not agree with the study conducted by [41] who show that about $50 \%$ of the isolates were production, $40 \%$ were moderate and about $10 \%$ did not production of this layer. And did not agree with the study [42] which found that about 57\% of MRSA had the ability to form slime layer and $43 \%$ of MRSA gave a negative result. In the current study It was revealed during that the isolate of MRSA has given black colonies on the media Congo red agar and did not lose the color of the dye even after more than a week and this result does not agree with the study of [43] who explained that the black colonies on the media of Congo red agar can lose dye after three days from incubation at room temperature. This indicate that isolates of the bacteria were more virulent as shown in Figure (6). 


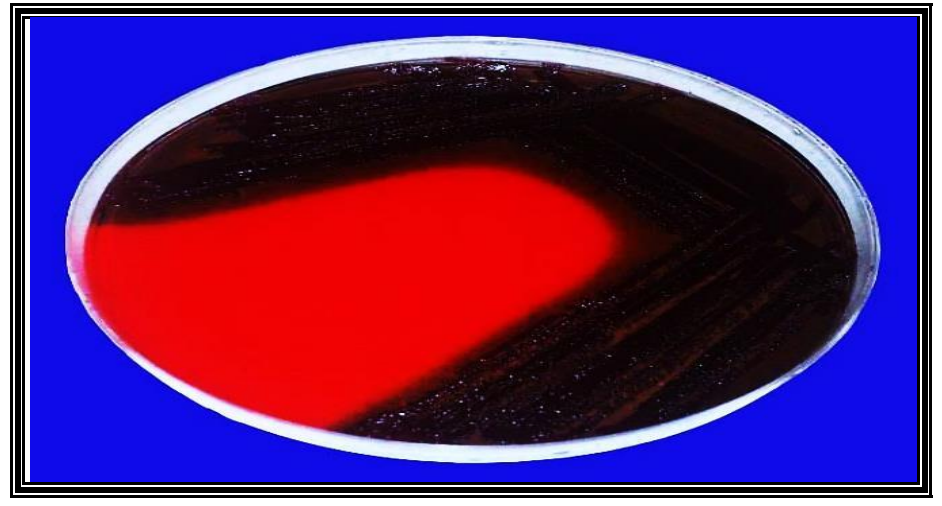

Figure (6): Slime layer Production from bacteria MRSA

[42] showed that the growth method on the Congo red agar was a realistic way to distinguish the phenotypic pattern of slime layer-producing isolates and high virulence and that it could help differentiate between strong and weak slime layer production, which reflects the severity of the infection and helps in determining the initial treatment. The difference in the degree of production of the slime layer is due to the difference in the production of polysaccharide adhesion (PIA) and reflects the change in genetic regulation. The growth method was used on the media Congo red agar to investigate the production of the slime layer of several isolates as an easy-to-use method, It is based on the promotion of the production of multiple polysaccharides using a rich medium, but it can be counted as a minor specialty and sensitivity due to differences that may occur in the formation of the black pigment of the colonies. Differences in the used culture media may affect the results of this method [44], [45].

\section{8- Capability Methicillin Resistance Staphylococcus aureus to the Production Biofilm:-}

The MRSA capability to biofilm production was detected using the tube- adhesion method [46]. 10 isolates were detected from MRSA biofilm producing. The results showed that 6 isolates were biofilm production while 4 isolates did not produce. as shown in Figure (7).

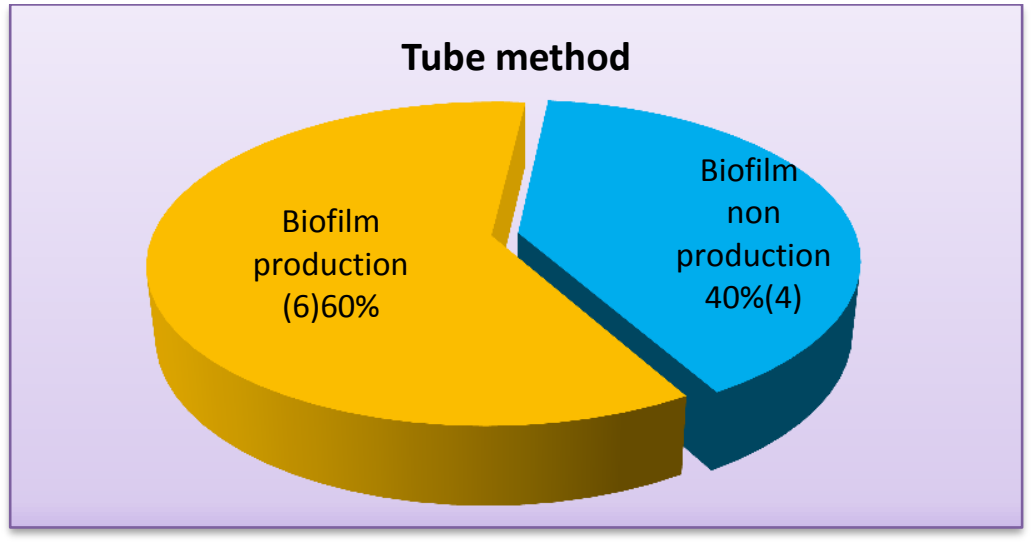

Figure (7): Production \& non-production isolates to biofilm

The results showed that most isolates have the ability to adhere to the glass tube walls that are stained with crystal violet compared with the control tube that contained no growth culture media, as shown in Figure (8). 


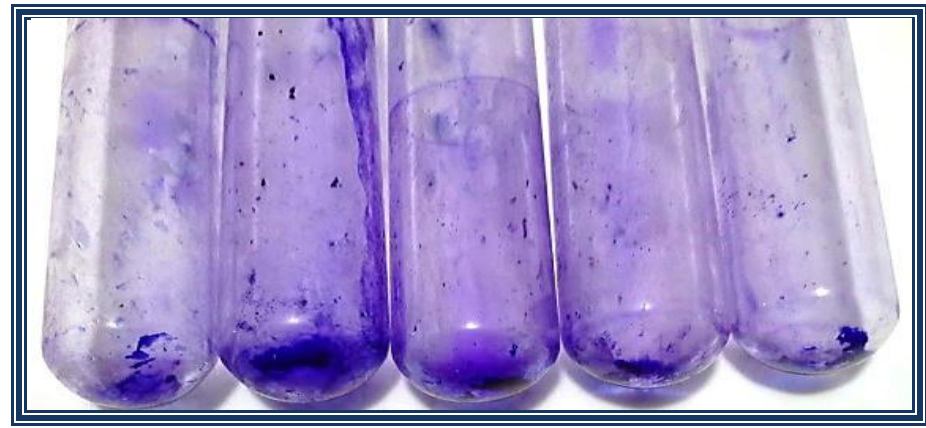

Figure (8): Biofilm Production by MRSA isolates

Show the growth of bacteria in the biofilm variations phenotypic different on the original strain that growth freely on the media. These variations include changes in movement, increased production of polysaccharides and increased resistance to antibiotics [47]. Adhesion dependent is highly on environmental conditions and changes in the culture media (8).

This result of the biofilm production screening in MRSA isolates were consistent with several studies that confirmed the MRSA susceptibility to biofilm production. (8) demonstrated the MRSA susceptibility to the biofilm production. Other studies have shown MRSA susceptibility to diffuse on solid surfaces and thus lead to biofilm formation [48].

\section{9- Capability Methicillin Resistance Staphylococcus aureus to the Production Capsule:-}

The investigated of 10 isolates from MRSA to the production of the capsule by means of microscopic examination of the bacteria using India ink stain figure (9). The results showed that all isolates were Capsule production, These isolates are Harmful the capsule is one of the virulence factors, This is confirmed by many studies which indicated that the capsule important role in the pathogenesis [49], [50].

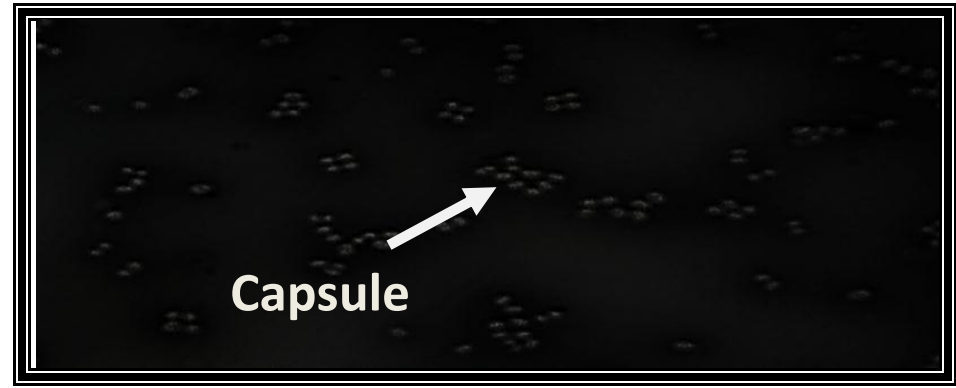

Figure (9): Microscopic Examination of the MRSA-produced capsule with stains India ink stain with magnification (1000X)

\section{0- Capability Methicillin Resistance Staphylococcus aureus to the Production Gelatinase:-}

The capability of all MRSA isolates was investigated for the production of the gelatinase. The results showed that only 7 isolates were able to produce the enzyme after an incubation period of 24-48 days while other isolates did not produce this enzyme even after incubation period more than 48 days.

The gelatinase is an important enzyme that increases the pathogenicity of bacteria as the enzyme works to break down the gelatin into the basic units from amino acids [51]. In addition, indicated [52] that the Gelatinase play an important role in the spread of cancerous tumors by destroying membrane components such as collagen, gelatin and proteoglycan compounds of the extracellular matrix. The results showed that some isolates have the ability to dissolve gelatin, to agreed with [53].

\section{1- Capability Methicillin Resistance Staphylococcus aureus to the Production Haemolysin:-}

The capability of 10 MRSA isolates to the production of haemolysin the was tested by the culture of bacteria on blood agar. The results showed differences in the isolation ratios of S.aureus to haemolysin production, they were 8 isolates with complete hemolysis represented by the appearance of a translucent around colony indicating the susceptibility of these isolates to the production of $\beta$-hemolysis, while the two isolates were partially $\alpha$-hemolysis, This result agreed with [54] reported that about $85.1 \%$ of $S$. aureus isolates were $\beta$ hemolysis. The capability of the bacteria to the $\beta$-hemolysis production of varying according to several factors, the most important is the source of red blood cells used in the culture media, which is through capability to detect of 
the bacteria to the production of $\beta$-hemolysis and also affected by the use test method, and the presence of serum and cholesterol in the blood used and Which leads to the inhibition process of hemolysis [55]. Therefore, S. aureus has the ability to produce haemolysin due to the osmotic properties posses to hemolysis the blood cells or because of the formation of pore holes in the cell or cytotoxic to dissolve types of human blood cells [56].

\section{2-Conclusion:-}

Our conclution that Staphylococcus aureus is highly resistant to $\beta$ - Lactam antibiotic and the CO-trimethoprim is the most effective in the inhibiting growth of this bacteria. In addition to its ability to produce virulence factors. The increase cause bacterial resistance to our local isolates may be due to the frequent use of antibiotics, which allowed for increased bacterial resistance to various antibiotics.

\section{CONFLICT OF INTERESTS}

\section{There are no conflicts of interest.}

\section{3- References}

[1] M.Aries-de-sousa, H.de-Lencastre, S.I Santos, K. Kikuchi, K.Totsuka, , and A.Tomasz, "'Similarity of antibiotic resistance patterns and molecular typing properties of methicillin-resistant Staphylococcus aureus isolated widely spread in hospitals in New York City and a hospital in Tokyo", Japan. Microbiol. Drug. Res. 6:253-258. 2000 .

[2] K.Marcus, "New bacteria on the block".J. Infect .Dis. 192:811- 818. 2005.

[3] G.Y.Liu, A.Essex, J.T Buchanan, V.Datta, H. M.Hoffman, J.F. Bastian, and V.Nizet, "Staphylococcus aureus golden pigment impairs neutrophil killing and promotes virulence through its antioxidant activity".J. Exp. Med. 202 (2): 209 - 215. 2005.

[4] K.K.Jefferson, D.A. Goldmann; and G.B. Pier. Use of confocal microscopy to analyze the rate of vancomycin penetration through Staphylococcus aureus Biofilms. Antimicrob. Agents. Chemother. 49(6):2467-2473. 2005.

[5] B.Krismer, and Peschel, A.Does Staphylococcus aureusnasal colonization involve biofilm formation. Future. Microbiol. 6:489-493. 2011.

[6] CLSI, Clinical and Laboratory Standards Institute. Performance standard for antimicrobial susceptibility testing; twelfth informational supplement .M100-S24. 2014.

[7] D.J.Freeman, F.R. Falkiner, and C.T. Keane. New method for detecting slime production by coagulase negative Staphylococci. J. Clin. Pathol. 42:872-874. 1989.

[8] T.Mathur, S. Singhal, S. Khan,; Upadhyay, D.J.; Fatma, T. and Rattan, A. Detection of biofilm formation among the clinical isolates of Staphylococci: An evaluation of three different screening methods. Indian .J. Med. Microbiol. 24(1):25-29. 2006.

[9] E.J.Bottone, L. Patel, P. Patel, and T.Robin. Mucoid encapsulated Enterococcus faecalis an emerging morphotype isolated from patients with urinary tract infections. Diagn. Microbiol. Infect. Dis. 31: 429-430. 1998.

[10] J.G.Collee, A.G. Fraser, B.P.Marmino, and A.Simons. Mackin and McCartney Practical Medical Microbiology. $14^{\text {th }}$ ed. The Churchill Livingstone. Inc. U.S.A. 1996.

[11] J.G.Collee, R.S.Miles, and B.Watt, “Test for The Identification of Bacteria”. In. J.G.131-149. 1996.

[12] K.Schleifer, and J. A. Bell. "Staphylococcus. In Bergey's Manual of Systematic Bacteriology”. A. C.Parte, , W. B.Whitman, P. De Vos, , G. M. Garrity, Dorothy Jones, N. R.Krieg, W. Ludwig, , F. A.Rainey, K. Schleifer and W. B. Whitman, ed. Biological Sciences Building University of Georgia Athens, GA -USA. p:392-420. 2009.

[13] J.H. Benson, "Microbiological applications: Laboratory Manual in General Microbiology". $8^{\text {th }}$ ed. McGraw Hill companies. New York. 2002.

[14] D. Mack, M.A. Horskotte, H. Rohde, and J.K-M. Knobloch. "Coagulase negative Staphylococci. In: Biofilms, infection, antimicrobial therapy”. Pace, J.L. Rupp, M.E. and Finch, R.G. 109-132. Taylor and Francis. New York. 2006.

[15] O.Schneewind, and D. Missiakas, "Staphylococcus aureusand Related Staphylococci". in:Goldman E. and Green L.H.(ed). Practical handbook of microbiology. $2^{\text {nd }}$ ed. CRC Press, New York.p.39. 2009.

[16] A.A.A. Al-Maliki. "A study of some Methicillin-Resistant Staphylococcus aureus (MRSA) and (MRSE) Isolated from Baghdad Hospital Patients”. M.Sc.Thesis. College of Science. AL-Mustansiriya University. 2009.

[17] H.A.H. Al-Geobory, "Comparative Study between Methicillin Resistant Staphylococcus aureus(MRSA) and Methicillin Sensitive Staphylococcus aureus(MSSA), and detect the Antimicrobial Effects of some Plant Extracts on them”. Msc. Thesis. College of Science/ Baghdad University. Iraq. 2011. 
[18] A.M. Al-Dahbi, and H.J. Al-Mathkhury, "Distribution of methicillin resistant Staphylococcusaureus in Iraqi patients and healthcare worker". Iraqi. J. Sci. 54: 293-300. 2013.

[19] K. R. Peck, J. Y. Baek, J-H. Song, and K. S. Ko, "Comparison of genotypes and enterotoxin genes between Staphylococcus aureus isolates from blood and nasal colonizers in Korean hospitals". J. Korean. Med. Sci.24:585591. 2009.

[20] M. Kolářr, J.Bardoň, V. Hanulík, P.Sauer, V. Babák, and J. Schlegelová. "Resistance to methicillin in coagulase-negative Staphylococci and Its Detection”. Acta. Vet. Brno.79:261-267. 2010.

[21] A. Ekrami, A.R. Samarbafzadeh, M. Alavi, E. Kalantar, and F. Hamzeloi. "Prevalence of methicillin resistant Staphylococcus sp isolated from burn patients in a burn center", Ahvaz, Iran. Jundishapur. J. Microbiol. 3: 84-91. 2010.

[22] A. Reipert,; K. Ehlert, T. Kast, and G.Bierbaum. "Morphological and genetic differences in two isogenic Staphylococcus aureus strains with decreased susceptibilities to vancomycin”. J. Antimicrob. Agents. Chemother. 47(2) : 568-576. 2003.

[23] B. Gonzalez-Zom, and P. Courvalin. "Van Amediated high level". Glycopeptide resistance in MRSA. Lancet. Infect.Dis.3:67-68. 2003.

[24] M.C.Booth, L.M. Pence, P. Mahasreshti, and M. S.“Gilmore, Clonal associations among Staphylococcus aureus isolates from various sites of infection”. Infect.Immun. 69: 345-352. 2001.

[25] W. Levinson, and E. Jawetz. "Medical Microbiology and Immunology :Examination \& Board Review $5^{\text {th }}$ ed". McGraw- Hill, U.S.A. p. 85-89. 2000.

[26] F.J. Schmitz, A.C. Fluit, D. Hofener, A. Beeck, M. Perdikouli, M. Boos, S. Schearing, F. Verhoef, K. Kohrer, and C. Von-Eiff. "Development of resistance to ciprofloxacin, ravampicin and mupirocin in methicillinsusceptible and resistance Staphylococcus aureus isolates". J. Antimicrobail. Agents. chemother. 44:3229-3231. 2000.

[27] G.F. Brooks, K.C. Carroll , J.S. Butel, and S.A. Morse. "Jawetz, Melnick and Adelbergs Medical Microbiology”. 24 ${ }^{\text {th }}$ ed. The McGraw-Hill Companies, Inc. New York. P.224-232. 2007.

[28] A. Norazah, V. K. Lim, S. N. Munirah, A. G. Kamel "Staphylococcus aureus carriage in selected communities and their antibiotic susceptibility patterns", Med. J. Malaysia. 58: 255-261. 2003.

[29] N.F. Col, and R.W. O`Connor. “Estimating worldwide current antibiotic usage: report of Task Force1.”. Rev. Infect. Dis. 9(3): 232- 43. 1987.

[30] C.M.Kunin, K.S.Juhansen, A.M. Worning, and F.D. Daschner. "Report of a symposium on use and abuse of antibiotics worldwide”. Rev. Infect. Dis. 12: 12-9. 1990.

[31] M.W. Ellis, M.E. Griffith, J.H. Jorgensen, D.R. Hospenthal, K. Mende, and J.E. Patterson. "Presence and molecular epidemiology of virulence factors in Methicillin-Resistant Staphylococcus aureusStrains colonizing and infecting soldiers". J. Clin. Microb. Bio. 47 (4): 940-945. 2009.

[32] Y. Omae, K. Sekimizu, and C. Kaito. "Identification of Staphylococcus aureus colony-spreading stimulatory factors from mammalian serum". PLoS ONE .9(5): 1-9. 2014.

[33] L. Cui, H. Murakami , K. Kuwahara-Arai, H. Hanaki , and K. Hiramatsu. "Contribution of a thickened cell wall and its glutamine nonamidated component to the vancomycin resistance expressed by Staphylococcus aureusMu50". Antimicrob. Agents Chemother. 44: 2276-2285. 2000.

[34] M. Kuroda, K. Kuwahara-Arai, and K. Hiramatsu. "Identification of the up and down-regulated genes in vancomycin-resistant Staphylococcus aureus strains Mu3 and Mu50 by cDNA differential hybridization method". Biochem. Biophys. Res. Commun. 269:485-490. 2000.

[35] K. Talaro, and A. Talaro. "Foundations in Microbiology Basic Principles". $2^{\text {nd }}$ ed, Mirror Higher Education Group, USA. Inc. 295. 1996.

[36] G.J. Tortora, B.R. Funke, and C.L.Case. "Microbiology. An Introduduction. 6thed. Benjamin/Cummings Publishing Company”. California, USA. P. 975. 1998.

[37] M. Kirisits, J.J. Margolis, B.L. Purevdorj-Gage، B. Vaughan, D.L. Chopp, P. Stooddley, and M.R. Parsek, "Influence of the hydrodynamic enviroment on quorum sensing in Pseudomonas aeruginosa Biofilms". $J$. Bacteriol. 189: 8357-8360. 2007.

[38] E. G. Kaya, E. Karakoç, S.Yagci, and M.Yücel. "Evaluation of phenotypic and genotypic methods for detection of methicillin resistance in Staphylococcus aureus". J. Afri. Microbiol. Res. 3(12): 925-929. 2009.

[39] H.M.H. Al-Hasani. "Comparative Study between Methicillin Resistant Coagulase Positive and Negative Staphylococci. Msc”. Thesis.College of Science/ Baghdad University. Iraq. 2011. 
[40] H. Akiyama, M. Uedo, H. Kanzaki, J. Tada, and J. Arata. "Biofilm formation of Staphylococcus aureus strains isolated from impetigo and furuncle: role of fibrinogen and fibrin”. J. Derm. Sci.16:2-10. 1997.

[41] E. B. Nori Al-Sheikh, and H. S. Yosif. "Study the effect of Lysostaphin, on methicillin resistant Staphylococcus aureus(MRSA) biofilm formation”.University of Baghdad, Iraq. J . Sci. 55(1):93-100. 2014.

[42] N. S. Mariana, S. A. Salman, V. Neela, S. Zamberi. "Evaluation of modified congo red agar for detection of biofilm produced by clinical isolates of methicillin resistance Staphylococcus aureus". Afr. J. Microbiol. Res. 3(6): 330-338. 2009.

[43] S. S. Seif El-Din, M. S. El-Rehewy, M. M.Ghazaly, M.H. Abd-Elhamid. "Biofilm formation by blood stream Staphylococcal isolates from febrile pediatric cancer patients at south Egypt cancer institute". J. American .Sci. 7(1):674-686. 2011.

[44] S. Murugan, P. U. Devi, P. N. John. "Antimicrobial susceptibility pattern of biofilm producing Escherichia coli of urinary tract infections”. Current Res. In .Bacteriol. 4(2): 73-80. 2011.

[45] G.D. Christensen, W.A. Simpson, A.L. Bisno, and E.H. Beachey. "Adherence of slime-producing strains of Staphylococcus epidermidis to smooth surfaces”. Infect. Immun. 37(1):318-326. 1982.

[46] A.J. Jesaitis, M. J. Franklin, D.Berglund. "Compromised host defense on Pseudomonas aeruginosa biofilms: Characterization of neutrophil and biofilm interactions”. J. Immunol. 171: 4329-4339. 2003.

[47] X. Wang, "Characterization of Escherichia coli Colonizing the Gastrointestinal Tract and Urinary Tract Catheters ". Karolinsk Institute, Stockholm, Sweden. P. 58. 2008.

[48] E. Tsompanidou, E.L. Denham, D.Becher, A. de Jong, G. Buist, M.Van Oosten, W.L.Manson, J.W.Back, J.M. Van Dijl, and A. Dreisbach. "Distinct roles of phenol-soluble modulins in spreading of Staphylococcus aureus on Wet Surfaces". Appl. Envir. Microbiol. 79(3): 886-895. 2013.

[49] GA Hebert, GA. "Hancock. Synergistic hemolysis exhibited by species of Staphylococci". J .Clin. Microbiol.22(3):409-415. 1985.

[50] CG.Gemmell. “Coagulase-negative Staphylococci”. J. Med. Microbiol. 22:282-295. 1986.

[51] M.J. Pickett, J.R. Greenwood, S.M. Harvey. "Test for detecting degradation of gelatin :Comparison of five methods". J. Clin. Microbiol. 29(10) : 2322-2325. 1991.

[52] M.A. Estefanía, G. S. Beatriz, A.Carlos, C. Cristina, C. Rosa, E. H.Pablo, H. Carmen, and M.C. Luis. "Antimicrobial activity, antibiotic susceptibility and virulence factors of lactic acid bacteria of aquatic origin intended for use as probiotics in aquaculture". BMC. Microbiol. 13(15):1-22. 2013.

[53] I . Stock , and B .Wiedemann. "Natural antibiotic susceptibility of Klebsiella pneumonia , $K$. oxytoca, $K$. planticola , K. ornithinolytica and K. terrigena strains “. J . Med. Microbiol . 50 :396-406 . 2001.

[54] A. S. Al-Jundiy. "Immunological Study on TSS-1 Toxin Extracted from Staphylococcus aureus Isolated from Infected Wounds”. Ph.D. Thesis. College of Science/ AL-Mustansyria University. Iraq. 2005.

[55] S. Hellerstein. "Urinary tract infection in children :pathophysiology ,risk factor and management" .Infect. Med. 19:554- 560. 2002.

[56] R. Al-Chalabi, A. Al-Ubaidy, and M.Al-Ibadi. "Detection of Urovirulence Genes (eae,E-hly, $\alpha$-hly) of Uropathogenic Escherichia coli by Specific PCR”. J. Biot. Res. Center.4 (1):44-54. 2010.

\section{عزل وتثخيص بكتريا المكور ات العنقودية الذهبية Staphylococcus aureus المقاومة

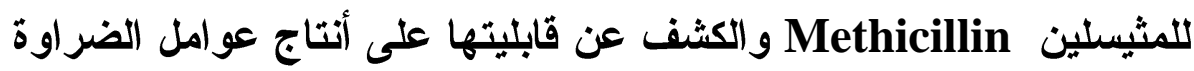$$
\text { الهاف: عزل ونتخيص بكتريا S.aureus ودر اسة قابليتها على إنتاج عو امل الضراوة. }
$$$$
\text { المواد والأساليب: جمعت } 50 \text { عينة سريرية لبكتريا Staphylococcus aureus في محافظة النجف الأشرف وللفترة من }
$$$$
\text { 2013/10/10 ولغاية 2014/1/20، نم التتخيص بالاعتماد على الخصائص المظهرية و الزرعية و الفحوصات الكيموحيويه، }
$$

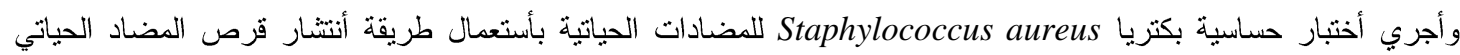$$
\text { بالإضافة إلى دراسة عو امل الضر اوة المنتجة من S.aureus. }
$$ 
النتائج: أظهرت النتائج أن المكورات العنقودية الذهيبة المقاومة للميثيسيلين شكلت حوالي 70٪ وان 30٪ من العزلات كانت

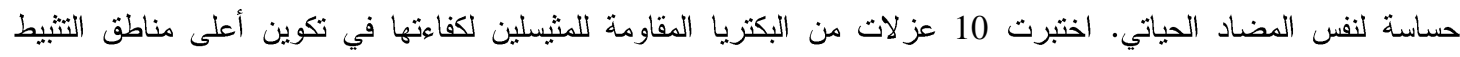

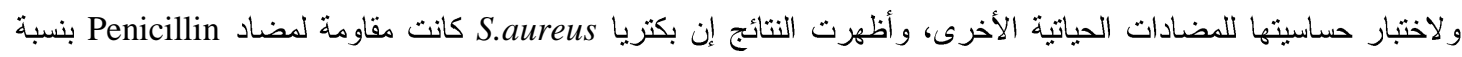

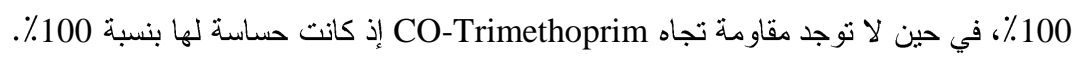

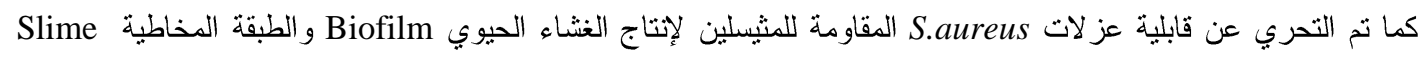

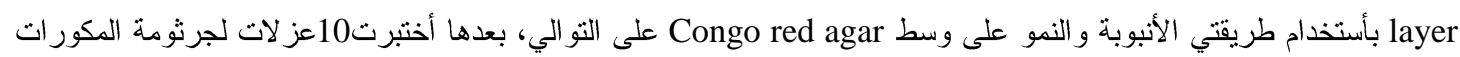
العنقودية اعتماداً على المقاومة للمثبسلين وقابليتها العالية على أنتاج الغثاء الحيوي و الطبقة المخاطية.

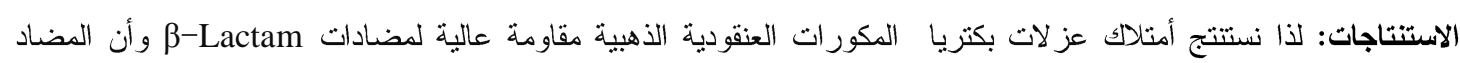

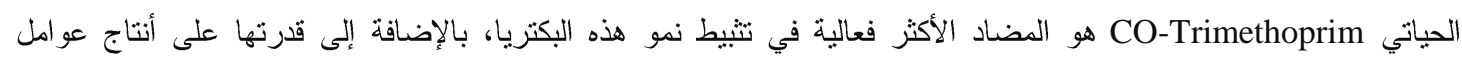

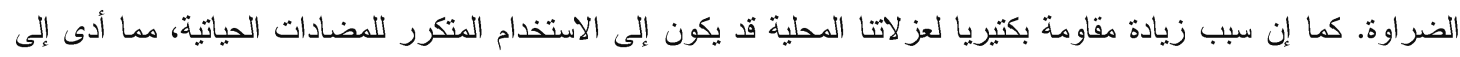
زيادة مقاومة البكتريا لمختلف المضادات الحيوية. الكلمات الدالة: المكورات العنقودية الذهيبة، الدضادات الحياتية، مثيسلين، عوامل الضراوة. 